\title{
SUPREME COURT STOP BULLFIGHT IN BRASIL
}

On October 6, 2016, the Supreme Court of Brazil ruled the Direct Unconstitutional Action n. 4983, proposed by the Federal General Attorney challenged the Act 15.299/2013 of Ceará State, which regulates a kind of brazilian bullfight called "vaquejada" considering It as a sport and cultural practice.

By 6 votes to 5 , the Justices considered that this practice subjects animals to cruelty, violating, therefore, the clause VII of $\S 1$ of article 225 of the Federal Constitution.

Although, the same Constitution, in its articles 215 and 216, deal on cultural environment, establishing that the State shall ensure to all the full exercise of cultural rights and the access to sources of national culture, protecting the manifestations of popular, indigenous and african-brazilian culture, and of other groups that participated in the national civilizing process.

Indeed, the roots of this cultural tradition, came from Portugal in colonial period, especially in the Northeast of Brazil, was a way for the cowboys to gather the cattle spread across the farm and surrounding region. On that culture, the action of overthrowing the runaway ox represented the entire control over the animal and the assurance that it would return to the possession of its owner.

For Câmara Cascudo, however, there is a distortion of this practice nowadays, which ceased to be a means of rural survival to became a "landocracy sport" [...] a real "public festival in the cities with advertising and speaker, photographs and urbanites applause."

It is important to note that what was at stake in the decision of the Brazilian Supreme Court was a collision between two fundamental rights: the fundamental right of society to a healthy and balanced environment - embraced in the right of the animals themselves not to be treated cruelly - in conflict with the right to freedom of expression. 
In the trial Justice Marco Aurélio Mello says:

The meaning of the word "cruelty", in the final sentence of paragraph VII of $\S 1$ of clause 225 of Constitution, reaches, without a doubt, the torture and mistreatment against the bovine animals during the contested practice, proving to be intolerable, and no longer possible, the human conduct authorized by the state norm attacked. In the context of the composition of the fundamental interests involved in this process, the claimed protection of the environment should win.

Justice Luis Roberto Barroso, in his turn, points out that:

In "Vaquejadas", the abrupt twist of the animal's tail at high speed and its overthrow necessarily with all four legs up, as required by the rule of the game, is inherently cruel and harmful to the animal. Even on situations where the physical and mental damages are not immediately visible, there is a chance of serious consequences that can manifest after the event. In any case, the simple relevant potential of injury is already able to trigger the incidence of the precautionary principle.

In the decisive vote, Justice Carmen Lucia Antunes Rocha uses an evolutionary interpretation to consider that the enactment of the Federal Constitution of 1988 changed the understanding of bullfihts, thus demonstrating that State of Ceará Act was unconstitutional for allowing the overthrow of the bull by the tail, a practice which, according to veterinary medical studies, effectively submits animals to cruelty and mistreatment.

In her vote, Justoce Carmen Lúcia Antunes Rocha says:

There will always be people who defend what comes from long time and It is rooted in the culture of our people. But cultures change and many of them were taken under this condition until there was another way of seeing life, not only the human way.

Howsoever, the Brazilian Supreme Court, following its own precedents in cockfighting and "farra do boi" cases, reaffirmed the prevalence of animal rights in relation to freedom of expression

Lastly, in this trial, the Brazilian Supreme Court adopts the Theory of Transcendence of Determinants Reasons, so that the "ratio decidendi" of the judgment will have "erga omnes" and binding effect in relation to the organs of Judiciary Power and the federal, state and municipal Public Administration.

It means that any national, state or municipal Act with similar content, that allows the "the overthrowof the bull by the tail", will be prevented from being applied, 
subjecting those who disobey the Supreme Court decision to judicial sanctions, as provided for article 32 of the Environmental Crimes Law (Law n. 9.605/98), which criminalizes the practice of acts of abuse, mistreatment, injury or mutilation of animals. 